\title{
HUBUNGAN KADAR PROCALCITONIN (PCT) DENGAN C-REACTIVE PROTEIN (CRP) PADA PASIEN INFEKSI DI RUMAH SAKIT PLUIT
}

\author{
*Lenggo Geni'), Lambok Marisi Rotua Panjaitan"1) \\ ${ }^{1}$ Program Studi D III Analis Kesehatan, Fakultas Kesehatan, Universitas Mohammad Husni Thamrin \\ Correspondence author: Lenggo Geni, lenggogeni19@gmail.com, Jakarta, Indonesia
}

\begin{abstract}
ABSTRAK
Di negara-negara berkembang termasuk Indonesia penyakit infeksi merupakan salah satu masalah kesehatan yang paling utama. Penyakit infeksi termasuk ke dalam 10 penyakit terbanyak rumah sakit di Indonesia. Penentuan diagnosis infeksi bakteri akut sering sulit, karena kemiripan gejala klinis dengan infeksi virus akut ataupun peradangan non infeksi, seperti trauma, reaksi penolakan organ donor, reaksi autoimun. Pemeriksaan Procalcitonin (PCT) dan CRP seringkali tidak sinkron meskipun keduanya merupakan pemeriksaan klinis untuk mendeteksi adanya infeksi. Penelitian ini dilakukan untuk mengetahui hubungan kadar Procalcitonin (PCT) dengan C-reactive protein (CRP) pada pasien infeksi di Rumah Sakit Pluit. Penelitian dilakukan dengan melihat data sekunder dari hasil pemeriksaan PCT dan CRP pada pasien dewasa dengan hasil leukosit lebih dari $10.000 / \mathrm{mm}^{3}$. Berdasarkan hasil penilitian dari 54 pasien yang mengalami infeksi di Rumah Sakit Pluit didapatlkan ada hubungan kadar PCT dengan CRP pada pasien infeksi sebesar 0.592 berada dalam rentang 0,41 - 0,70 yang berarti bahwa kadar PCT dengan kadar CRP memiliki hubungan yang cukup. Persentase pasien yang mengalami infeksi berdasarkan jenis kelamin didapatkan bahwa jenis kelamin laki-laki lebih tinggi yaitu $55,6 \%$ dibandingkan pasien wanita yaitu 44,4\%. Persentase pasien yang mengalami infeksi dapatkan jumlah terbanyak pada usia $>65$ tahun, yaitu 28 orang (51,9\%). Hasil pemeriksaan PCT di dapatkan hasil 38,9\% di atas normal dan hasil pemeriksaan CRP didapatkan hasil 90,7\% di atas normal. Hal ini menunjukkan bahwa peningkatan kadar CRP mempunyai persentase yang lebih tinggi dibandingkan dengan peningkatan kadar PCT.
\end{abstract}

Kata kunci : Infeksi, Procalcitonin (PCT), C-reactive protein (CRP).

\begin{abstract}
In developing countries including Indonesia infectious diseases are one of the most major health problems. Infectious diseases are among the top 10 hospital diseases in Indonesia. Determining the diagnosis of acute bacterial infection is often difficult, due to the similarity of clinical symptoms to acute viral infections or noninfectious inflammation, such as trauma, donor organ rejection reactions, autoimmune reactions. Procalcitonin (PCT) and CRP examinations are often out of sync even though they are clinical examinations to detect infection.

This research was conducted to find out the relationship of Procalcitonin (PCT) levels with C-reactive protein $(C R P)$ in infectious patients at Pluit Hospital. The study was conducted by looking at secondary data from pct and CRP screening results in adult patients with leukocytes results of more than 10,000/ $\mathrm{mm}^{3}$. Based on the results of the study of 54 patients who had infections in Pluit Hospital found there is a relationship of PCT levels with CRP in infectious patients of 0.592 is in the range of $0.41-0.70$ which means that PCT levels with CRP levels have sufficient relationships. The percentage of patients who had an infection based on gender was found to be $55.6 \%$ higher than female patients at 44.4\%. The percentage of patients with the infection had the highest number at the age of 65 , which was 28 people (51.9\%). Pct test results were $38.9 \%$ above normal and CRP test results were $90.7 \%$ above normal. This indicates that the increase in CRP rate has a higher percentage compared to the increase in PCT levels.
\end{abstract}

Keywords : Infection, Procalcitonin (PCT), C-reactive protein (CRP).

Open Journal System (OJS): journal.thamrin.ac.id

http://journal.thamrin.ac.id/index.php/anakes/issue/view/33 


\section{PENDAHULUAN}

Tubuh manusia tidak mungkin terhindar dari lingkungan yang mengandung mikroba patogen disekelilingnya. Penyakit infeksi pada manusia dapat ditimbulkan oleh mikroba patogen. Mikroba patogen yang ada bersifat poligenik dan kompleks. Oleh karena itu respons imun tubuh manusia terhadap berbagai macam mikroba patogen juga berbeda. Pada umumnya mekanisme imun mana yang berperan untuk proteksi ditentukan oleh gambaran biologik spesifik mikroba. (Judarwanto, 2012)

Di negara-negara berkembang termasuk Indonesia penyakit infeksi merupakan salah satu masalah kesehatan yang paling utama. Berdasarkan Survei Kesehatan Rumah Tangga Tahun 2007, penyebab utama kematian antara lain 28,1 \% disebabkan oleh penyakit infeksi dan parasit, 18,9\% disebabkan oleh penyakit vaskuler, dan 15,7 \% disebabkan oleh penyakit pernapasan. Banyaknya angka kematian pada anak Indonesia yaitu lebih dari 200 anak meninggal per 100.000 angka kelahiran merupakan hal yang menjadi pertimbangan. Angka ini masih jauh dari MDGs (Millennium Development Goals) Negara Indonesia di tahun 2015 yaitu 102 per 100.000 kelahiran. Penyakit infeksi yang termasuk ke dalam 10 penyakit terbanyak rumah sakit di Indonesia diantaranya penyakit diare, demam tifoid, demam berdarah, infeksi saluran pernapasan atas (influenza, radang amandel, radang tenggorokan), radang paru-paru, dan demam yang belum diketahui penyebabnya (observasi febris). (Mutsaqof, S.T, \& S., 2015)

Penentuan diagnosis infeksi bakteri akut sering sulit, karena kemiripan gejala klinis dengan infeksi virus akut ataupun peradangan non infeksi, seperti trauma, reaksi penolakan organ donor, reaksi autoimun. Dengan pemeriksaan kultur, diagnosis infeksi bakteri dapat ditegakkan secara pasti, tetapi hasil pemeriksaannya membutuhkan waktu yang lama. Oleh karena itu, adanya suatu penanda yang dapat menggambarkan adanya infeksi bakteri akut pada awal perjalanan penyakit dapat sangat membantu mengarahkan rencana terapi, mengurangi penggunaan antoibiotik yang tidak rasional, dan memperbaiki outcome jangka panjang. (Atmadja, Kusuma, \& Dinata, 2016)

Pemeriksaan endotoksin, PCT, CRP, leukosit, IT ratio, dan neoptrin merupakan beberapa pemeriksaan laboratorium klinis untuk mendeteksi adanya infeksi dalam darah. (Iskandar, Pudjiadi, Mulyo, Pratiwi, \& Suryatin, 2010).

Peran utama leukosit atau sel darah putih adalah pertahanan tubuh melawan infeksi. Batas normal jumlah sel darah putih berkisar antara 4000 sampai 10.000/ $\mathrm{mm}^{3}$. Peningkatan leukosit yang umumnya lebih dari $10.000 / \mathrm{mm}^{3}$ menunjukkan leukositosis. Peningkatan leukosit sebagai respons fisiologis untuk melindungi tubuh dari serangan mikroorganisme. (Price \& Wilson, 2005)

Procalcitonin (PCT) merupakan salah satu indikator biokimia yang paling penting yang berkorelasi erat dengan keparahan reaksi inflamasi host terhadap infeksi mikroba. Kadar PCT meningkat selektif

Open Journal System (OJS): journal.thamrin.ac.id 
pada kasus infeksi bakteri, sedangkan pada kasus infeksi virus konsentrasinya tetap normal. (Suhaymi, Fikri, \& Nasution, 2016)

C-reactive protein (CRP) adalah suatu mediator inflamasi non-spesifik, merupakan indikator yang sensitive untuk infeksi bakteri, peradangan, dan kerusakan jaringan. (Suhaymi, Fikri, \& Nasution, 2016)

Pemeriksaaan PCT dan CRP merupakan pemeriksaan yang banyak dilakukan di Rumah Sakit Pluit dibandingkan pemeriksaan lain yang merupakan pemeriksaan klinis untuk mendeteksi adanya infeksi. Penulis melihat walaupun PCT dan CRP merupakan indikator untuk mendeteksi adanya infeksi dalam darah, namun ketika kedua pemeriksaan tersebut dilakukan hasil yang didapatkan seringkali menunjukkan perbedaan, saat hasil PCT tinggi hasil CRP tidak selalu tinggi dan sebaliknya.

Berdasarkan latar belakang di atas, maka penulis tertarik untuk melakukan penelitian yang berjudul "Hubungan Kadar Procalcitonin (PCT) Dengan C-Reaktive Protein (CRP) Pada Pasien Infeksi di Rumah Sakit Pluit”.

\section{METODOLOGI PENELITIAN}

Penelitian dilakukan di Laboratorium Rumah Sakit Pluit dilakukan pada bulan Mei 2018. Populasi dari penelitian ini adalah Pasien infeksi dengan hasil leukosit lebih dari 10.000/ $\mathrm{mm}^{3}$ di Rumah Sakit Pluit. Sampel Penelitian ini adalah Data hasil pemeriksaan PCT dan CRP di Rumah Sakit Pluit dari Desember 2017 sampai dengan Maret 2018. Dalam pengumpulan data, penulis menggunakan data sekunder yaitu data hasil pemeriksaan kadar PCT dan CRP pada pasien di Laboratorium Rumah Sakit Pluit. Langkah-langkah sebagai berikut : Membuat surat izin pengambilan data di Rumah Sakit Pluit. Melakukan rekapitulasi data pemeriksaan PCT dan CRP dengan hasil leukosit lebih dari 10.000/ $\mathrm{mm}^{3}$ dalam bentuk tabel. Mengolah dan menganalisa data hasil pemeriksaan laboratorium pemeriksaan PCT dan CRP di Rumah Sakit Pluit. Data yang diperoleh adalah data sekunder dari hasil pemeriksaan PCT dan CRP dengan hasil leukosit lebih dari 10.000/. $\mathrm{mm}^{3}$. Untuk menghitung hubungan antara PCT dengan CRP sebagai penanda infeksi data dianalisis bivariat dengan menggunakan uji kolerasi nonparametrik Spearman.

Open Journal System (OJS): journal.thamrin.ac.id 


\section{HASIL PENELITIAN DAN PEMBAHASAN}

\section{Hasil penelitian}

Data pasien infeksi yang melakukan pemeriksaan PCT dan CRP di laboratorium Rumah Sakit Pluit dari Desember 2017 sampai dengan Maret 2018 didapatkan 54 pasien.

Tabel 1

Distribusi frekuensi pemeriksaan PCT dan CRP di laboratorium Rumah Sakit Pluit dari Desember 2017 sampai dengan Maret 2018 berdasarkan jenis kelamin

\begin{tabular}{lcc}
\hline Jenis kelamin & Jumlah & Persentase (\%) \\
\hline Laki-laki & 30 & 55.6 \\
Wanita & 24 & 44.4 \\
\hline Total & 54 & 100.0 \\
\hline
\end{tabular}

Berdasarkan tabel 1 dari data 54 pasien terdiri dari 55,6\% (30 orang) pasien laki-laki dan 44,4\% (24 orang) pasien wanita yang melakukan pemeriksaan PCT dan CRP dengan hasil leukosit lebih dari $10.000 / \mathrm{mm}^{3}$ di Rumah Sakit Pluit.

Tabel 2

Distribusi frekuensi pemeriksaan PCT dan CRP di laboratorium Rumah Sakit Pluit dari Desember 2017 sampai dengan Maret 2018 berdasarkan kelompok usia

\begin{tabular}{|c|c|c|c|c|c|}
\hline \multirow{2}{*}{ Usia } & \multirow{2}{*}{$\begin{array}{l}\text { Jumlah } \\
\text { Pasien }\end{array}$} & \multicolumn{2}{|c|}{ Kadar CRP } & \multicolumn{2}{|c|}{ KadarProcalcitonin } \\
\hline & & $\mathbf{N}$ & $>\mathbf{N}$ & $\mathbf{N}$ & $>\mathbf{N}$ \\
\hline \multirow{2}{*}{$\begin{array}{c}18-40 \\
\text { (Dewasa muda) }\end{array}$} & \multirow{2}{*}{13} & 2 & 11 & 12 & 1 \\
\hline & & $3.7 \%$ & $20.4 \%$ & $22.2 \%$ & $1.9 \%$ \\
\hline \multirow{2}{*}{$\begin{array}{c}41-65 \\
\text { (Dewasapenuh) }\end{array}$} & \multirow{2}{*}{13} & 0 & 13 & 5 & 8 \\
\hline & & $0.0 \%$ & $24.1 \%$ & $9.3 \%$ & $14.8 \%$ \\
\hline \multirow{2}{*}{$\begin{array}{c}>65 \\
\text { (Lanjut usia) }\end{array}$} & \multirow{2}{*}{28} & 3 & 25 & 16 & 12 \\
\hline & & $5.6 \%$ & $46.3 \%$ & $29.6 \%$ & $22.2 \%$ \\
\hline \multirow[b]{2}{*}{ Total } & \multirow{2}{*}{54} & $9.3 \%$ & $90.7 \%$ & $61.1 \%$ & $38.9 \%$ \\
\hline & & \multicolumn{2}{|c|}{$100 \%$} & \multicolumn{2}{|c|}{$100 \%$} \\
\hline
\end{tabular}

Keterangan: Pengelompokan usia dewasa berdasarkan Prof. $\quad$ Dr.Koesoemanto Setyonegoro.

Berdasarkan tabel 2 dari kelompok umur pasien yang melakukan pemeriksaan PCT dan CRP dengan hasil leukosit lebih dari $10.000 / \mathrm{mm}^{3}$ di Rumah Sakit Pluit di dapatkan hasil pada usia 18 - 40 tahun sebanyak 13 orang $(24,1 \%)$ pemeriksaan PCT hasil normal 12 (22,2\%), hasil di atas normal $1(1,9 \%)$, pemeriksaan CRP hasil normal 2 (3,7\%), hasil di atas normal 11 (20,4\%). Pada usia 41 - 65 tahun 
sebanyak 13 orang $(24,1 \%)$ pemeriksaan PCT hasil normal 5 (9,3\%), hasil di atas normal $8(14,8 \%)$, pemeriksaan CRP hasil normal $0(0,0 \%)$, hasil di atas normal $13(24,1 \%)$. Pada usia $>65$ tahun sebanyak 28 orang $(51,9 \%)$ pemeriksaan PCT hasil normal $16(29,6 \%)$, hasil di atas normal 12 (22,2\%), pemeriksaan CRP hasil normal 3 (5,6\%), hasil di atas normal 25 (46,3\%).

Tabel 3

Pemeriksaan PCT dan CRP di laboratorium Rumah Sakit Pluit dari Desember 2017 sampai dengan Maret 2018 berdasarkan nilai minimum, maksimum, standar deviasi dan rata-rata

\begin{tabular}{lcc}
\hline & PCT $\mathbf{( n g / m L )}$ & CRP (mg/ L) \\
\hline Kadar terendah & 0.07 & 5.19 \\
\hline Kadar tertinggi & 79.34 & 198.96 \\
\hline Standar Deviasi & 10.875 & 60.042 \\
\hline Rata-rata & 2.38 & 83.79 \\
\hline
\end{tabular}

Berdasarkan tabel 3 hasil pemeriksaan PCT kadar terendah 0,07 ng/mL dan kadar tertinggi 79,34 $\mathrm{ng} / \mathrm{mL}$ mempunyai standar deviasi 10,875 dengan rata-rata 2,38 ng/mL. Hasil pemeriksaan CRP kadar terendah 5,19 mg/L dan kadar tertinggi 198,96 mg/L mempunyai standar deviasi 60,042 dengan ratarata $83,79 \mathrm{mg} / \mathrm{L}$.

Tabel 4

Kadar Procalcitonin (PCT) dan C-Reactive Protein (CRP) Berdasarkan uji normalitas dengan analisis Kormogorov-Smirnov

\begin{tabular}{lccc}
\hline & Statistik & Df & Sig. \\
\hline Kadar Procalcitonin & 0.415 & 54 & 0.000 \\
\hline Kadar CRP & 0.117 & 54 & 0.065 \\
\hline
\end{tabular}

Berdasarkan tabel 4 setelah dilakukan uji normalitas pada 54 data pasien dengan analisis Kormogorov-Smirnov di dapatkan hasil populasi data berdistribusi tidak normal, maka hubungan kadar PCT dan CRP di analisa menggunakan uji nonparametric Spearman.

\section{Tabel 5}

Hubungan kadar Procalcitonin (PCT) dan C-Reactive Protein (CRP) berdasarkan hasil uji nonparametric Spearman

\begin{tabular}{ccc}
\hline & p-value & Nilai $r$ \\
\hline PCT & 0.000 & 0.592 \\
CRP & 0.000 & 0.592 \\
\hline
\end{tabular}

Berdasarkan tabel 5 dari hasil uji kolerasi nonparametrik Speraman hubungan kadar Procalcitonin dengan CRP didapatkan nilai siginifikan ( $p$-value) 0,000 dan nilai koefisien kolerasi (r) 0,592 . 


\section{Pembahasan}

Berdasarkan data pasien infeksi yang melakukan pemeriksaan PCT dan CRP di laboratorium Rumah Sakit Pluit dari Desember 2017 sampai dengan Maret 2018 didapatkan 54 pasien. Proporsi pasien yang mengalami infeksi berdasarkan jenis kelamin didapatkan bahwa jenis kelamin laki-laki lebih banyak yaitu 55,6\% dari pada wanita yaitu 44,4\%. Pada pria diproduksi hormone androgen yang bersifat imunosupresan sehingga memperkecil resiko penyakit autoimun tetapi tidak membuat lebih kebal terhadap infeksi.Hasil ini didapat juga pada penelitian Setyawati (2006) yang dilakukan di RSUP DR. Sardjito Yogyakarta yang menunjukkan distribusi sepsis lebih banyak pada jenis kelamin laki-laki. Hal tersebut berhubungan dengan faktor genetik dan kromosom yang berperan penting dalam sistem pertahanan tubuh (Khair, 2010).

Berdasarkan distribusi pada usia pasien di dapatkan jumlah terbanyak pada usia $>65$ tahun, yaitu 28 orang $(51,9 \%)$. Hal ini dapat disebabkan karena dengan bertambahnya usia, fungsi biologis mengalami penurunan akibat proses degeneratif (penuaan) yang akan menurunkan daya tahan tubuh sehingga usia yang lebih tua rentan terkena infeksi penyakit. Pola hidup yang juga dijalani sejak usia balita adalah faktor yang juga mempengaruhi kondisi fisik dan daya tahan tubuh manula. Pola hidup yang kurang sehat berdampak pada penurunan daya tahan tubuh. (RI K. K., 2013)

Berdasarkan hasil pemeriksaan PCT dengan nilai normal $<0,5 \mathrm{ng} / \mathrm{mL}$ di dapatkan sebanyak $61,1 \%$ hasil normal dan 38,9\% di atas normal. Kadar PCT terendah 0,07 ng/mL dan kadar tertinggi 79,34 $\mathrm{ng} / \mathrm{mL}$. Hasil pemeriksaan CRP dengan nilai normal $<10 \mathrm{mg} / \mathrm{L}$ didapatkan sebanyak 9,3\% hasil normal dan 90,7\% di atas normal. Kadar CRP terendah 5,19 mg/L dan kadar tertinggi 198,96 mg/L. Hal ini menunjukkan bahwa peningkatan kadar CRP mempunyai persentase yang lebih tinggi dibandingkan dengan peningkatan kadar PCT.

Hal ini sejalan dengan penelitian Dharaniyadewi dkk yang menyatakan kadar CRP tetap tinggi walaupun keadaan disfungsi organ dan inflamasi sistemik tidak berat. Sedangkan kadar PCT meningkat sesuai dengan beratnya disfungsi organ, sepsis berat atau syok sepsis. Kadar PCT mencapai puncak lebih cepat dan menurun lebih cepat daripada CRP. Kadar CRP mencapai puncak dalam 2-3 hari dan tetap tinggi selama beberapa hari kemudian. Kadar PCT meningkat dan menurun lebih cepat dari pada CRP karena berkaitan dengan kinetika PCT. Kadar PCT mencapai puncak dalam 1 hari dan hal ini dapat membantu diagnosis lebih cepat 24-48 jam sebelum terjadi peningkatan kadar CRP. (Dharaniyadewi, Lie, \& Suwarto, 2015)

Berdasarkan hasil uji kolerasi nonparametrik Spearman didapatkan nilai signifikansi (p) 0,000 dan nilai koefisien korelasi (r) 0,592 , Nilai signifikansi penelitian ini lebih kecil dari $\alpha(0,05)$, yang berarti 
bahwa kadar PCT mempunyai hubungan yang signifikan dengan kadar CRP. Koefisien korelasi berada dalam rentang 0,41 - 0,70 yang berarti bahwa kadar PCT dengan kadar CRP memiliki korelasi yang cukup. Hasil penelitian ini konsisten dengan penelitian yang dilakukan oleh Iskandar dkk. Penelitian yang dilakukan oleh Iskandar dkk menemukan adanya kolerasi antara kadar PCT dengan kadar CRP.

Hubungan atau korelasi cukup antara PCT dengan CRP karena kadar PCT mencapai puncak lebih cepat dan menurun lebih cepat daripada CRP. (Dharaniyadewi, Lie, \& Suwarto, 2015). Kadar PCT meningkat selektif pada kasus infeksi bakteri, sedangkan pada kasus infeksi virus konsentrasinya tetap normal. (Suhaymi, Fikri, \& Nasution, 2016) sedangkan CRP adalah suatu mediator inflamasi nonspesifik, merupakan indikator yang sensitifuntuk infeksi bakteri, peradangan, dan kerusakan jaringan. (Suhaymi, Fikri, \& Nasution, 2016).

\section{SIMPULAN}

Dari hasil analisis data pasien yang mengalami infeksi yang melakukan pemeriksaan PCT dan CRP di laboratorium Rumah Sakit Pluit dari Desember 2017 sampai dengan Maret 2018 dapat di simpulkan sebagai berikut : Persentase pasien yang mengalami infeksi berdasarkan jenis kelamin didapatkan bahwa jenis kelamin laki-laki lebih tinggi yaitu 55,6\% dibandingkan pasien wanita yaitu 44,4\%. Persentase pasien yang mengalami infeksi dapatkan jumlah terbanyak pada usia $>65$ tahun, yaitu 28 orang (51,9\%). Hasil pemeriksaan PCT di dapatkan hasil 38,9\% di atas normal dan hasil pemeriksaan CRP didapatkan hasil 90,7\% di atas normal. Hal ini menunjukkan bahwa peningkatan kadar CRP mempunyai persentase yang lebih tinggi dibandingkan dengan peningkatan kadar PCT. Ada hubungan kadar PCT dengan CRP pada pasien infeksi sebesar 0.592 berada dalam rentang 0,41 - 0,70 yang berarti bahwa kadar PCT dengan kadar CRP memiliki hubungan yang cukup.

\section{UCAPAN TERIMA KASIH}

Penulis mengucapkan terima kasih kepada Rumah Sakit Pluit, dan Prodi D III Analis Kesehatan Fakultas Kesehatan Universitas MH Thamrin. dalam penelitian ini. 


\section{DAFTAR PUSTAKA}

1. Atmadja, A. S., Kusuma, R., \& Dinata, F. (2016). Pemeriksaan Laboratorium untuk Membedakan Infeksi Bakteri dan Infeksi Virus. CDK-241, 43 (6), 457-461.

2. Buchori, \& Prihartini. (2006). Diagnosis Sepsis Menggunakan Procalcitonin.Indonesian Journal of Clinical Phatology and Medical Laboratory, 12 (3), 127-133.

3. Dharaniyadewi, D., Lie, K. C., \& Suwarto, S. (2015). Peran Procalcitonin sebagai Penanda Inflamasi Sistemik pada Sepsis.Jurnal Penyakit Dalam Indonesia, 2 (2), 116123.

4. Guyton, AC, Hall JE. 2007. Buku ajar Fisiologi Kedokteran. Edisi 11 . Jakarta. EGCD

5. Iskandar, H. R., Pudjiadi, A., Mulyo, D., Pratiwi, A., \& Suryatin, Y. (2010). Sensitifitas dan Spesifisitas Pemeriksaan Procalcitonin, C-Reactive Protein (CRP), dan Hitung Leukosit untuk Memprediksi Infeksi Bakterial pada Sindrom Syok Dengue di Pediatric Intensive Care Unit. Sari Pediatri, 12 (4), 233-240.

6. Judarwanto, W. (2012, 2 14). Imunologi Dasar:Mekanisme Pertahanan Tubuh $\begin{array}{lllll}\text { Terhadap } & \text { Bakteri. } & \text { Retrieved } & 517, & \text { from }\end{array}$ http://allergicliniconline.com/2012/02/14/imunologi-dasar-mekanisme-pertahanantubuh-terhadap-bakteri/

7. Marzony, I., Yani, F. F., \& Efrida. (2016). Uji Diagnostik C-Reactive Protein Pada Pneumonia Bakteri Komunitas Anak. Sari Pediatri, 17 (5), 391-395.

8. Mutsaqof, A. A., S.T, c., \& S., E. S. (2015). Sistem Pakar Untuk Mendiagnosis Penyakit Infeksi Menggunakan Forward Chaining. Jurnal Itsmart, 4 (1), 43-47.

9. Price, S. A., \& Wilson, L. M. (2005). Patofisiologi : Konsep Klinis Proses-Proses Penyakit.(H. Hartanto, Ed., \& B. U. Pendit, Trans.) Jakarta: EGC.

10. Radji, M. (2010). Buku Ajar Mikrobiologi : Panduan Mahasiswa Farmasi \& Kedokteran.(J. Manurung, Ed.) Jakarta: EGC.

11. RI, K. K. (2013). Buletin Jendela Data \&Informasi Kesehatan. Gambaran Kesehatan Lanjut Usia Di Indonesia, 9-11.

12. Sherwood, Lauralee. 2012. Fisiologi Manusia dari Sel ke Sistem Edisi 6. Jakarta. EGC

13. Suhaymi, E., Fikri, E., \& Nasution, I. P. (2016). Perbandingan Akurasi Diagnostik Kadar Procalcitonin Dan C-Reactive Protein Pada Pasien Appendisitis Anak Di RSUP H.Adam Malik Medan Dan RSUD Dr. Pirngadi Medan. CKD-245, 43 (10), 727-731.

14. http://pdf.medicalexpo.com/pdf/boditech-med-inc/ichroma/67878-144253.html. (n.d.). 
15. https://assets.thermofisher.com/TFS-Assets/CDD/Package-Inserts/brahms-kryptor-pctsensitive-ifu-825-050.pdf. (n.d.) 
